\title{
Effects of nest success and mate fidelity on breeding dispersal in a population of Snowy Plovers Charadrius nivosus
}

\author{
WENDY J. PEARSON and MARK A. COLWELL
}

\begin{abstract}
Summary
Breeding dispersal subsequent to nest failure is hypothesised to be a behavioural response to danger posed by nest predators. We used histories and locations of male and female Snowy Plover Charadrius nivosus nests in northern California over a 10-year period to examine effects of nest fate, mate fidelity, residency, predator exclosures, and age on dispersal distance. Within years, females moved a median distance of $2.2 \mathrm{~km}$ after changing mates; males moved a median of $0.9 \mathrm{~km}$. Between years, plovers moved the shortest distances when they retained a mate from the prior year and were successful in hatching eggs (males $=0.2 \mathrm{~km}$, females $=0.3 \mathrm{~km}$ ). Both females $(13.0 \mathrm{~km})$ and males $(2.6 \mathrm{~km})$ dispersed farther when mate change coincided with nest failure in the prior year. The observation that most plovers did not disperse far enough to move away from sites where predators are abundant and have strong effects on plover reproductive success suggests that effective predator management will be challenging.
\end{abstract}

\section{Introduction}

Breeding dispersal is an important life history trait critical to population viability (Clobert et al. 2001, Ronce et al. 2001), especially for endangered or threatened species (Hanski 2001). Dispersal is thought to be influenced by an individual's experiences, including reproductive success (Haas 1998, Hoover 2003, Catlin et al. 2005, Skrade and Dinsmore 2010, Rioux et al. 2011). In birds, predation is a primary cause of reproductive failure (Ricklefs 1969, Martin 1993), and dispersal from low quality sites is one of several strategies that has evolved to reduce the risk of nest predation and increase reproductive success (Lima 2009). For example, experimentally induced nest failure increased dispersal of American Robins Turdus migratorius and Brown Thrashers Toxostoma rufum (Haas 1998). Based on such findings, the "decision rules" hypothesis predicts that individuals that breed successfully disperse shorter distances than those that fail (Haas 1998, Hoover 2003).

Other factors may influence dispersal, including availability of a breeding site and a mate (Clobert et al. 2001). High site fidelity (i.e. low dispersal) has been linked with the return of a mate from a previous breeding season (Haig and Oring 1988, Flynn et al. 1999, Forero et al. 1999, Catlin et al. 2005) and the competitive advantage accrued by returning to a territory (Greenwood 1980). For example, Black Kites Milvus migrans that lost their mates were less faithful to their territory (Forero et al. 1999), and Burrowing Owls Athene cunicularia that divorced dispersed farther than those that nested with their prior mate.

The Pacific coast population of the Snowy Plover Charadrius nivosus (hereafter, plover) was listed as threatened under the United States Endangered Species Act in 1993 (United States Department of Interior 1993). Both human disturbance and predation on eggs and chicks have direct, negative effects on plover reproductive success (Colwell et al. 2011), and therefore, may 
affect dispersal. The species' recovery plan defined six recovery units extending from Washington south through California; Recovery Unit 2 (hereafter, RU2) includes Mendocino, Humboldt, and Del Norte counties of California (United States Department of Interior 2007). In RU2, an increasing proportion of the small (19-74 adults) population has bred on a few sandy, ocean-fronting beaches where high predation rates severely compromise individual reproductive success (Colwell et al. 2010a, Burrell and Colwell 2012), with the potential to influence dispersal. Managers have attempted to ameliorate the low reproductive success using various non-lethal methods such as nest exclosures that protected eggs from predators and increased hatching success (Hardy and Colwell 2008). Recently, Colwell et al. (2010b) drew upon the decision rules hypothesis to propose that, before considering lethal methods, managers allow predation to continue unmanaged to cause unsuccessful plovers to disperse. This proposal assumed that dispersal distances of failed breeders would result in plovers moving sufficient distances so that they occupied higher quality sites where predators had less impact on reproductive success. The low population size of RU2 suggests that there is habitat available to support dispersing individuals (Burrell and Colwell 2012).

Along the Pacific coast, the plover's mating system of sequential monogamy is coupled with unequal gender roles in parental care: males and females share incubation but males provide nearly all care for chicks (Page et al. 1995). In RU2, predators cause most reproductive failure (Burrell and Colwell 2012). However, plovers readily renest over the long ( 120 day; March-July) breeding season. These conditions provide opportunities to examine dispersal both within and between seasons, in association with reproductive success and knowledge of mate availability. Based on the decision rules hypothesis (Haas 1998, Hoover 2003), we examined relationships between dispersal of plovers and nesting success. Specifically, we predicted that individuals whose nests failed to hatch eggs would disperse greater distances than those that were successful. We evaluated our results in the context of management actions directed at reducing negative impacts of predation specifically. Plovers breed on beaches that are favored by humans for recreation and humans occasionally cause reproductive failure in a manner similar to predation (Colwell et al. 2010a). As a result, plovers and the beaches they occupy sometimes require intensive management (e.g. restrictions on access). For this reason, understanding the manner in which plovers disperse among sites in response to reproductive success and failure is critical to effective conservation.

\section{Methods}

\section{Study area}

Biologists have studied a colour-marked population of plovers since 2001 in Humboldt County, California (Figure 1) in two distinct habitats: 1) 60 km of ocean-fronting beaches and 2) gravel bars of the lower Eel River, $\sim 15 \mathrm{~km}$ from its mouth at the Pacific Ocean (Colwell et al. 2010a). A homogeneous sandy substrate characterised most beaches, whereas gravel bars had a heterogeneous substrate of varying stone size. On beaches, plovers nested amidst a variety of debris such as sea grass bundles, brown algae (e.g. Fucus, Egregia), driftwood, stones, shells, and garbage. Vegetation along beaches consisted of European beach grass Ammophila arenaria and sparse native vegetation (e.g. Cakile maritima, Abronia spp.). Sparse stands of willow Salix spp. and white sweet clover Melilotus alba occurred commonly along the gravel bars. Colwell et al. (2O10a) provided a detailed description of the study area.

\section{Field methods}

Since 2001, nearly all plovers breeding in Humboldt County have been captured and marked with a unique combination of coloured bands (Mullin et al. 2010). We marked newly hatched chicks on the right leg with a single metal band wrapped with brood-specific coloured tape. Each year, from mid-March through to late August, observers surveyed suitable habitat for breeding plovers at approximately 7-10 day intervals. When observers detected evidence of breeding (adults, nests, or 


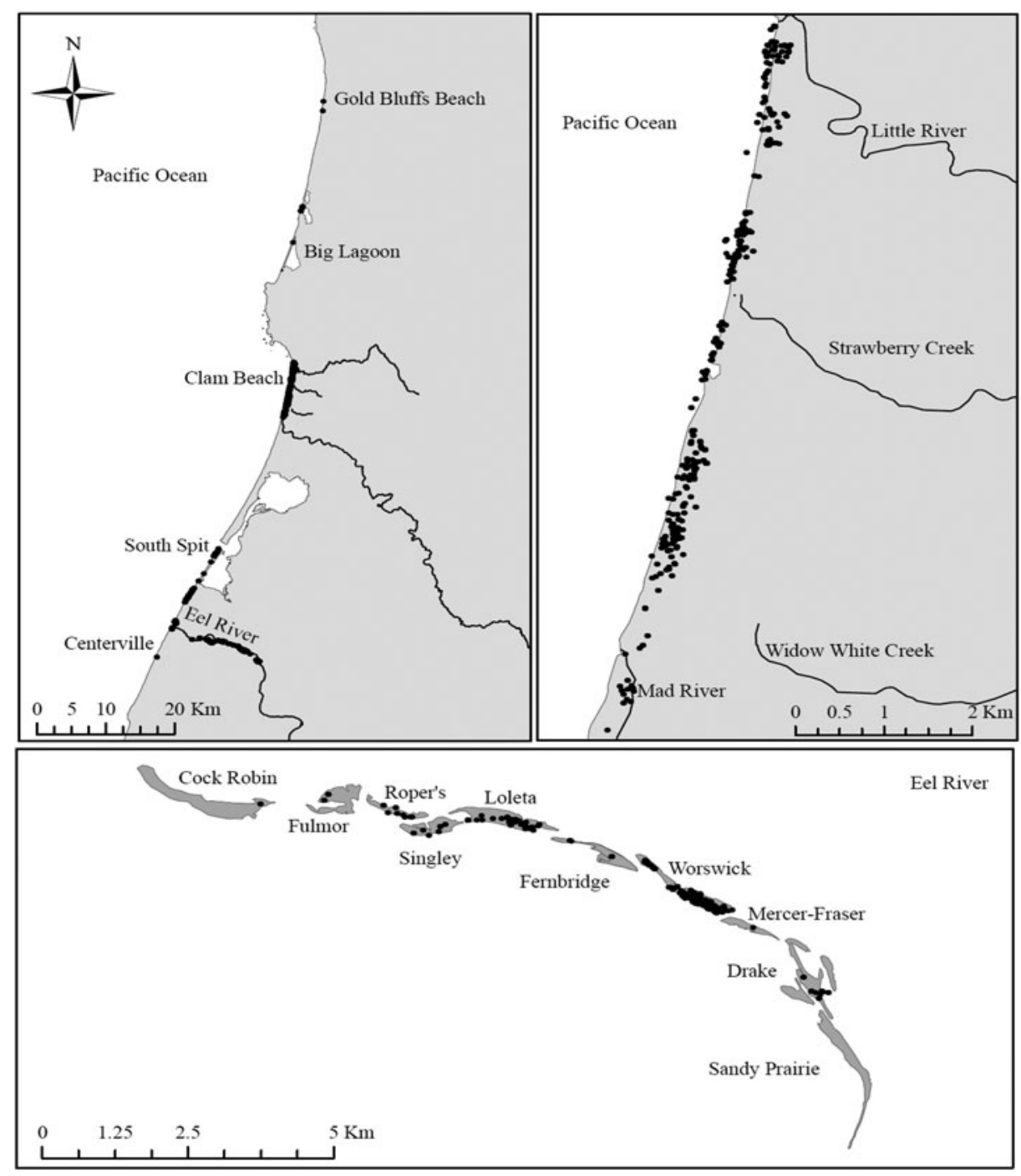

Figure 1 . Nest locations $(\bullet$ ) within Humboldt County (a) where observers monitored a colourmarked population of Snowy Plovers from 2001 to 2010. Detail of nest locations at Clam Beach and Mad River are shown in (b). Individual gravel bars along the lower Eel River are shown in (c).

broods), we increased the frequency of surveys. When observers found nests or chicks, they ascribed ownership to marked adults based on observed incubation, brooding of chicks, or presence near a nest (Mullin et al. 2010, Colwell et al. 2010a). Observers recorded nest locations using a hand-held Global Positioning System (GPS) or a personal digital assistant (PDA) equipped with a GPS (Dell Axim 50 with Holux GR-271; positional accuracy $\pm 3 \mathrm{~m}$ ). We used this information to compile a 10-yr (2001-2010) dataset consisting of nest ownership, nest fate (hatched at least I chick or failed), and locations (UTM coordinates). We removed from analyses 31 of 576 nests because we could not determine nest ownership or the owners were not uniquely colour-banded. Occasionally, observers located males brooding newly hatched chicks from an unknown nest $(n=8)$, in which case we used the brood location as the nest location. We knew that some individuals $\left(n_{\text {males }}=4\right.$, 
$\left.n_{\text {females }}=7\right)$ dispersed to Oregon and Washington. We included these individuals and their nests $(n=18)$ in analyses. Observers conducted research under federal (United States Fish and Wildlife Service TE-823807-3), state (Department of Fish and Game \#SC0496; Department of Parks and Recreation \#08-635-011), and university (IACUC \#08/09.W.23.A and 04/05.W.17-A) permits.

\section{Definitions and statistical analyses}

We analysed breeding dispersal both within season and between seasons because virtually all plovers initiated multiple $(2-10)$ nests over $\sim 120$ days and most males $(52 \%)$ and females $(60 \%)$ renested (1-9 times) within a season. We used a Geographic Information System (GIS) to quantify dispersal as the straight-line distance (m) (Colwell et al. 2007) between an individual's successive nests within a year using ArcGIS (ESRI, Redlands, California) and Hawth's Analysis Tools (Beyer 2004). For between-season dispersal, we measured the distance between the last nest of a year and first nest of the subsequent year (Colwell et al. 2007). To improve normality of residuals, we transformed $(\mathrm{ln})$ all distances. We also assessed breeding dispersal categorically by defining a dispersing individual as one that moved more than $\bar{x}+1$ SD home range size between nests (Pearson 2011); results from both methods were similar and only those from the continuous analysis are reported here. We analysed males and females separately because dispersal has been shown to differ between the sexes (Greenwood 1980), and because inclusion of males and females tending the same nest would violate assumptions of independence.

We modeled dispersal distance as a function of multiple covariates (Table 1 ), using best subsets regression (Minitab 15 Statistical Software 2007). Initially, we used combinations of $1-5$ variables and summed the frequency with which a variable occurred in the top model and number of times it was included in one of the top five models. We omitted from further analysis variables that were never in the top model or that were included in less than $25 \%$ of the top five models (FL, Prior, and Exposure days); variables that were included for further analysis were in more than $49 \%$ of the top models. Using variables from the best subsets regression analysis and our existing knowledge of the species biology and life history traits, we selected a candidate set of models (Pearson 2011) for testing using linear mixed effects models in R statistical software (Pinheiro et al. 2011). We treated individuals as a random effect within maximum likelihood models because we had multiple observations of each individual. We ranked models using Akaike's Information Criterion corrected for small sample size $\left(\mathrm{AIC}_{c}\right)$. To account for uncertainty in model selection, we averaged parameter estimates using the relative weight $\left(\mathrm{AIC}_{w}\right)$ from each model receiving up to $90 \%$ of the support from the complete candidate model set (Burnham and Anderson 2002). We report untransformed distances as medians with inter-quartile range because of the strong effect of a few long-distance dispersers.

\section{Results}

Over 1o years, we found 576 nests, of which 547 belonged to 228 uniquely marked plovers (104 males and 124 females). Males tended $3.7 \pm 0.6$ nests each year $(n=67)$, which provided 250 dispersal distances between consecutive breeding attempts; females $(n=77)$ nested $3.7 \pm 0.4$ times providing 284 dispersal distances. The between-season analyses included 123 and 106 paired nest locations from males and females, respectively. Many individuals (males $=27 \%$, females $=32 \%$ ) had a single nest in the study area or nested for only one breeding season (males $=47 \%$, females $=48 \%$ ). Males tended an average of $4.6 \pm 0.6$ nests over $2.2 \pm 0.2$ years, whereas females nested an average of $4.1 \pm 0.4$ times over $1.9 \pm 0.1$ years. The oldest male in the population (nine years in 2010) tended 41 nests; the oldest female (seven years in 2010) nested six out of seven seasons contributing 19 nests.

Breeding dispersal varied greatly both within and between seasons (Figure 2), although most individuals (within $=92 \%$, between $=85 \%$ ) dispersed less than $10 \mathrm{~km}$. The top model examining within-season dispersal of both males and females (Tables 2 and 3 ) indicated that plovers that 
Table 1. Definitions of variables used in analysis of breeding dispersal of Snowy Plovers from 2001-2010 in Humboldt County, California.

\begin{tabular}{|c|c|c|c|}
\hline Variable & Definition & Analysis & Values \\
\hline Age & $\begin{array}{l}\text { The minimum age (in years) of an individual. This is the known } \\
\text { age for individuals marked as chicks }(n=70) \text {; unmarked } \\
\text { immigrants were assumed to be yearlings. }\end{array}$ & Both & $1-9$ \\
\hline Available Mates & $\begin{array}{l}\text { The maximum number of opposite sex individuals at a site up to } \\
5 \text { days before or after the hatch or failure of a nest calculated } \\
\text { using geo-referenced individual location data collected from } \\
\text { o1 March-29 July (2005-2010). }\end{array}$ & Within & $0-13$ \\
\hline Excl & $\begin{array}{l}\text { A nest protected from vertebrate predators by using a nest } \\
\text { exclosure (i.e. cage). }\end{array}$ & Both & $\mathrm{Y}, \mathrm{N}$ \\
\hline Exposure Days & $\begin{array}{l}\text { Number of days eggs were exposed calculated using the } \\
\text { Mayfield (1975) method. }\end{array}$ & Both & $0-41$ \\
\hline Day & Day on which nest was found beginning or March. & Both & $0-155$ \\
\hline Habitat & Substrate in which the nest was located: beach (B) or gravel (G). & Both & $\mathrm{B}, \mathrm{G}$ \\
\hline HF & The nest hatched $(\mathrm{H})$ or failed $(\mathrm{F})$. & Both & $\mathrm{H}, \mathrm{F}$ \\
\hline FL & $\begin{array}{l}\text { The number of chicks that survived more than } 28 \text { days after } \\
\text { hatch (Page et al. 1995). }\end{array}$ & Both & $0-3$ \\
\hline \multirow[t]{2}{*}{ Mate } & $\begin{array}{l}\text { An individual that retained a mate between successive nesting } \\
\text { attempts within a breeding season. }\end{array}$ & Within & $\mathrm{Y}, \mathrm{N}$ \\
\hline & $\begin{array}{l}\text { An individual that paired with the same mate at any time in the } \\
\text { following year. }\end{array}$ & Between & $Y, N$ \\
\hline Origin & $\begin{array}{l}\text { An individual that hatched within the study area and returned to } \\
\text { breed }(n=66) \text {. }\end{array}$ & Both & $\mathrm{Y}, \mathrm{N}$ \\
\hline Prior & $\begin{array}{l}\text { An individual whose current mate was "available" for the next } \\
\text { nesting attempt. If the prior nest failed, the mate was assumed } \\
\text { to be available. }\end{array}$ & Within & $\mathrm{Y}, \mathrm{N}$ \\
\hline \multirow[t]{2}{*}{ Success } & $\begin{array}{l}\text { An individual's cumulative number of clutches that hatched at } \\
\text { least } 1 \text { chick, including the current nest. }\end{array}$ & Within & $0-9$ \\
\hline & $\begin{array}{l}\text { An individual that hatched at least one chick in the study area at } \\
\text { any time in that breeding season. }\end{array}$ & Between & $\mathrm{Y}, \mathrm{N}$ \\
\hline Winter & $\begin{array}{l}\text { Individual observed within the study area during the non-breeding } \\
\text { season for at least one year. }\end{array}$ & Both & $\mathrm{Y}, \mathrm{N}$ \\
\hline
\end{tabular}

retained mates and had hatched more nests moved shorter distances between nesting attempts than those that changed mates when renesting or had fewer successes; between-season patterns were similar. Individual variation accounted for a small proportion of the variance in the data within season $($ males $=27 \%$, females $=25 \%$ ) and between seasons $($ males $=34 \%$, females $=4 \%$ ).

\section{Nesting success}

Of the 250 male and 284 female movements for which a within-season dispersal distance was calculated, 45 and 59 of these, respectively, followed a nest success. Within a breeding season, male dispersal distance correlated negatively with cumulative successes (Table 4). Males that hatched at least one clutch moved a median distance of $0.7 \mathrm{~km}(0.2-1.4)$ vs. $1.3 \mathrm{~km}(0.4-3.0)$ for those that never hatched a clutch. A similar effect occurred between years. Plovers dispersed shorter distances after successful breeding the prior year (Table 4). Dispersal distance was calculated for 123 male and 106 female between-season movements, of which 101 and 84, respectively, followed a breeding season in which the individual successfully hatched at least one clutch. Males that hatched at least one clutch moved a median distance of $0.3 \mathrm{~km}(0.1-1.8)$ as compared to $2.2 \mathrm{~km}(0.5-4.9)$ for unsuccessful males. Successful females (0.8 km; $0.2-3.9)$ nested nearer their last nest of the previous year compared with unsuccessful females $(2.9 \mathrm{~km} ; 1.2-27.3)$. 

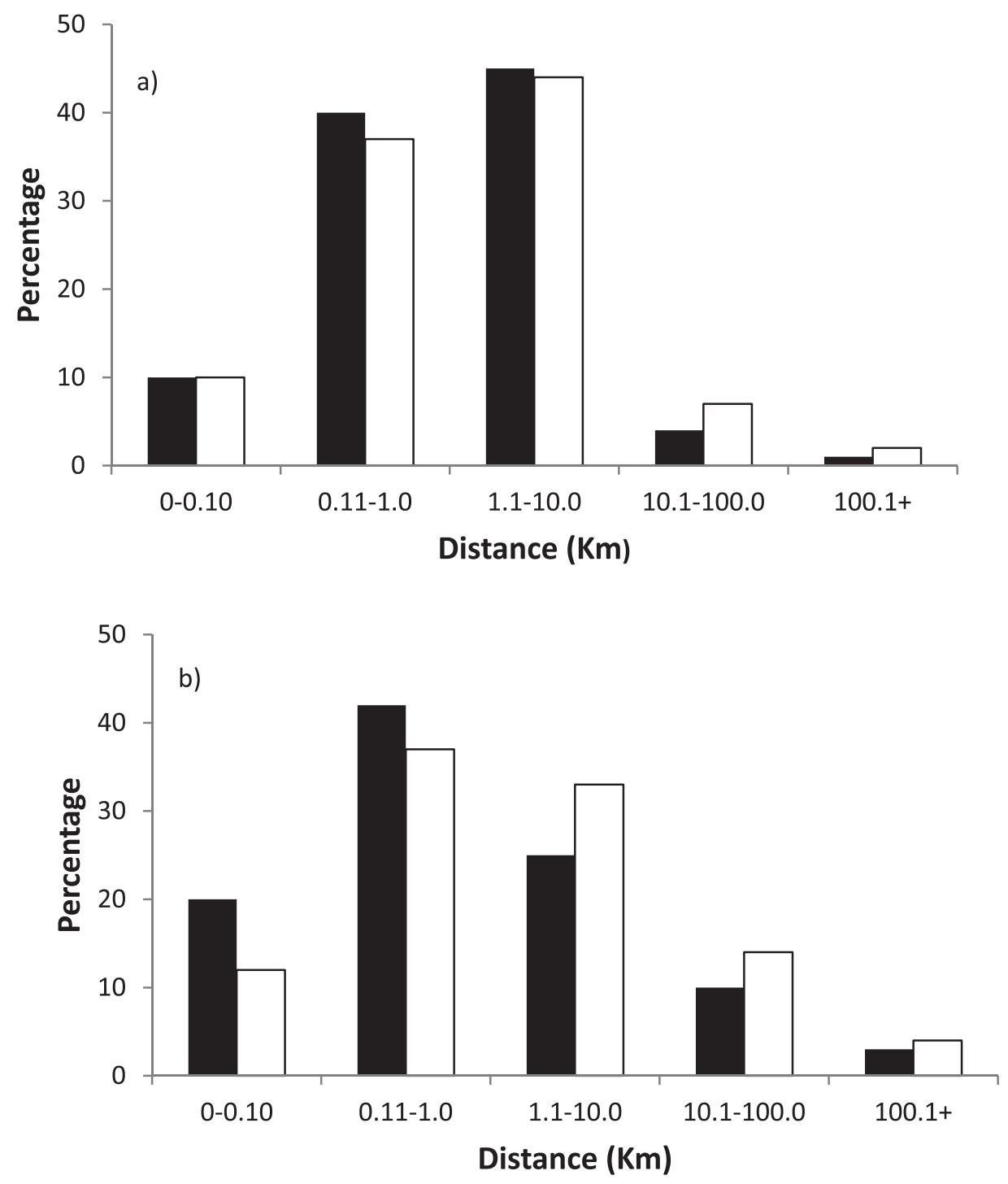

Figure 2. Frequency distribution of distance moved between nesting attempts a) within a single breeding season and $b$ ) between the last and first nests of consecutive breeding seasons for male (匹) and female (口) Snowy Plovers breeding in Humboldt County, California, 2001-2010.

\section{Mate fidelity}

Within a season, most males $(82 \%)$ and females $(78 \%)$ retained mates following clutch failure (Fisher's Exact Test, $P<0.001, n=534$ ). Males moved $0.9 \mathrm{~km}$ (median; $0.3-2.5$ ) after mate change within a season (Table 4); females (Table 4 ) moved $2.2 \mathrm{~km}$ (median; $0.4-5.8$ ) after changing mates. Conversely, both males $(n=55)$ and females $(n=62)$ moved approximately the same distance of $1.0 \mathrm{~km}(0.3-2.3)$ between nesting attempts when they did not change mates. Site fidelity was not associated with mate availability for either sex (females, Fisher's Exact Test, $P=0.33$; males, Fisher's Exact Test, $P=0.13)$. However, $83 \%(n=58)$ of females and $88 \%(n=60)$ of males 
Table 2. Models selected from the candidate model set receiving up to $90 \%$ of the total weight for withinseason breeding dispersal of male and female Snowy Plovers. $\mathrm{K}=$ number of parameters, $\mathrm{AIC}_{c}=\mathrm{Akaike}^{\prime} \mathrm{s}$ Information Criterion corrected for small sample size, $\Delta \mathrm{AIC}_{c}=$ difference between the $\mathrm{AIC}_{c}$ of the current model and the top model, $\mathrm{AIC}_{w}=$ model weight.

\begin{tabular}{lllllllll}
\hline \multicolumn{7}{l}{ Male } & \multicolumn{7}{l}{ Female } \\
\hline Covariate & $\mathrm{K}$ & $\mathrm{AIC}_{c}$ & $\Delta \mathrm{AIC}_{c}$ & $\mathrm{AIC}_{w}$ & $\mathrm{~K}$ & $\mathrm{AIC}_{c}$ & $\Delta \mathrm{AIC}_{c}$ & $\mathrm{AIC}_{w}$ \\
\hline Mate + Success & 5 & 468.18 & $\mathrm{O}$ & 0.58 & 5 & 580.65 & 0 & 0.41 \\
Mate & 4 & 471.35 & 3.17 & 0.12 & 4 & 581.03 & 0.38 & 0.34 \\
Success + Age & 5 & 472.60 & 4.42 & 0.06 & - & - & - & - \\
Success & 4 & 472.73 & 4.55 & 0.06 & - & - & - & - \\
Mate + Day & 5 & 473.52 & 5.33 & 0.04 & 5 & 582.93 & 2.29 & 0.13 \\
Success + Winter & 5 & 474.65 & 6.47 & 0.02 & - & - & - & - \\
HF + Success + Age & 6 & 474.79 & 6.61 & 0.02 & - & - & - & - \\
Day + Winter + Origin + Mate & - & - & - & - & 7 & 585.46 & 4.82 & 0.04 \\
Habitat & - & - & - & - & 4 & 585.93 & 5.28 & 0.03 \\
\hline
\end{tabular}

remained within a home range when there were multiple potential mates available at their site within five days of the hatch or failure of their nest.

Between seasons, adults nested closer to their prior year's last nest when they retained a mate from the prior year (Table 4). In most cases, when females (61\%) and males (66\%) were site faithful, they paired with a mate from the prior year. Plovers moved the shortest distances when they retained a mate from the prior year and were successful (males $=0.2 \mathrm{~km}[0.1-0.5]$, females $=0.3 \mathrm{~km}[0.1-2.3])$. Conversely, when mate change was coupled with nest failure in the prior year, females moved a median of $13.0 \mathrm{~km}(2.6-37.5)$ as compared to a median of $2.6 \mathrm{~km}(1.1-6.4)$ moved by males.

\section{Other variables}

Habitat type was associated with dispersal of males (Table 4). Males on gravel bars nested nearer a previous year's nest (0.3 km; 0.I-1.2) compared with beaches (0.8 km; 0.2-3.4). In females, all other parameters in models receiving $90 \%$ of the total weight had $95 \%$ unconditional confidence intervals overlapping zero.

Table 3. Models selected from the candidate model set receiving up to $90 \%$ of the total weight for betweenseason breeding dispersal of male and female Snowy Plovers. $\mathrm{K}=$ number of parameters, $\mathrm{AIC}_{c}=\mathrm{Akaike}^{\prime} \mathrm{s}$ Information Criterion corrected for small sample size, $\Delta \mathrm{AIC}_{c}=$ difference between the $\mathrm{AIC}_{c}$ of the current model and the top model, $\mathrm{AIC}_{w}=$ model weight.

\begin{tabular}{lcclllllll}
\hline \multicolumn{7}{c}{ Male } & \multicolumn{7}{c}{ Female } \\
\hline Covariate & $\mathrm{K}$ & $\mathrm{AIC}_{c}$ & $\Delta \mathrm{AIC}_{c}$ & $\mathrm{AIC}_{w}$ & $\mathrm{~K}$ & $\mathrm{AIC}_{c}$ & $\Delta \mathrm{AIC}_{c}$ & $\mathrm{AIC}_{w}$ \\
\hline Mate + Success & 5 & 545.00 & $\mathrm{O}$ & 0.41 & 5 & 459.20 & 0 & 0.97 \\
Mate & 4 & 547.55 & 2.55 & 0.11 & 4 & 468.44 & 9.24 & 0.01 \\
Success + Winter & 5 & 547.72 & 2.72 & 0.10 & - & - & - & - \\
Success + Mate + Habitat + Day + & 12 & 548.91 & 3.91 & 0.06 & 12 & 468.41 & 9.20 & 0.01 \\
$\quad$ Winter + Origin + Age + HF & & & & & & & & - \\
Habitat & 4 & 549.23 & 4.23 & 0.05 & - & - & - & - \\
Excl & 4 & 549.28 & 4.29 & 0.05 & - & - & - & - \\
Mate + Day & 5 & 549.65 & 4.65 & 0.04 & 5 & 470.56 & 11.36 & 0.00 \\
Success & 4 & 550.46 & 5.46 & 0.03 & 4 & 471.17 & 11.97 & 0.00 \\
HF & 4 & 550.59 & 5.59 & 0.03 & - & - & - & - \\
Winter & 4 & 550.62 & 5.62 & 0.02 & - & - & - & - \\
\hline
\end{tabular}


Table 4. Parameter estimates $(\beta)$ and $95 \%$ confidence intervals of model-averaged within- and between-season breeding dispersal using ln distance moved between nesting attempts for male and female Snowy Plovers.

\begin{tabular}{llccc}
\hline & Within-season & \multicolumn{3}{l}{ Between-season } \\
\hline Parameter & Male & Female & Male & Female \\
\hline Intercept & $6.85(6.21-7.49)$ & $6.79(6.14-7.43)$ & $6.82(6.14-9.00)$ & $7.30(8.10-9.89)$ \\
Change (Yes) & $0.88(0.23-1.54)$ & $1.20(0.51-1.88)$ & $1.09(0.25-1.92)$ & $1.70(0.83-2.56)$ \\
Success (Yes) & $-0.25(-0.45--0.05)$ & $-0.20(-0.44-0.04)$ & $-1.12(-2.21--0.03)$ & $-1.67(-2.64--0.71)$ \\
Habitat (Gravel) & & & $-1.01(-1.87--0.14)$ & \\
\hline
\end{tabular}

\section{Discussion}

Dispersal is a form of behaviour that has evolved, in part, to lessen the negative impact of predation on individuals (Lima 2009). Our findings support the "decision rules" hypothesis as plovers dispersed greater distances between successive nests (both within and between season) after they failed to hatch chicks. Moreover, dispersal distances differed between habitats, with slightly greater dispersal occurring along beaches where reproductive failure is much more common than on gravel bars (Colwell et al. 2010a). Our findings corroborate results for other species of bird (Catlin et al. 2005, Forero et al. 1999), including plovers (Flynn et al. 1999, Skrade and Dinsmore 2010, Rioux et al. 2011). Others, however, have found no relationship between nest success and dispersal as indexed by the proportion of adults that return to breed in an area (Haig and Oring 1988, Wiens and Cuthbert 1988).

With few exceptions, most movements by Snowy Plovers were quite localised and confined to a restricted linear stretch of ocean-fronting beach or riverine gravel bar. Most males and females moved $<3 \mathrm{~km}$ between nesting attempts (both within and between seasons), which resulted in many attempts to renest occurring within the average home range size of plovers in northern California (Pearson 2011). Conversely, a few individuals (especially females) that were unsuccessful at hatching chicks, dispersed long distances (>100 km). Dispersal distance was also associated with mate retention, with individuals that retained a mate moving shorter distances both within and between seasons. A similar pattern was obtained for between-season dispersal: plovers that paired with a mate from the previous breeding season tended to move short distances and settle near their last nest of the prior year.

Our finding that dispersal was linked to reproductive success differs from at least one published account for this species. Stenzel et al. (1994) found no differences in long-distance dispersal for plovers that hatched or failed to hatch eggs in central California. This difference may arise from analytical procedures. We analysed all nests for an individual whereas Stenzel et al. (1994) examined dispersal following early-season nests (those initiated prior to 15 May). In a preliminary analysis of natal dispersal ( $n=62$ plovers of known age; 2001-2006) from our study area, Colwell et al. (2007) reported no significant difference in dispersal between plovers that were successful or not in hatching young. Our findings, using different analytical techniques and a larger sample, clarify this result to show that dispersal was affected by cumulative hatching success.

The relationship between mate fidelity and dispersal may vary among plover populations owing to several factors associated with their breeding biology, including length of breeding season coupled with sequential polygamy, low breeding density, and high rates of nest failure. In northern California, plovers exhibit sequential monogamy and initiate clutches over $\sim 120$ days (Colwell et al. 2010a). This long interval affords considerable time for individuals to find potential mates following failed clutches. Females may attempt a maximum of three successful breeding attempts within a season; males, on the other hand, can breed successfully at most twice in a season because they invest more in parental care of chicks. As a result, the mating system favors frequent opportunities to disperse, especially among females that compete for males as the limiting sex that invests more in parental care (Emlen and Oring 1977). A similar pattern held for dispersals between seasons. 
The plovers we studied were located near the northern extent of the species' range, where densities are low (Colwell et al. 2010a). As a result, individuals may have fewer options in the immediate vicinity to change mates within a breeding season. In other words, individuals must roam widely in search of mates. Some females dispersed long distances within a breeding season to nest later in the season in Oregon and Washington; some of these individuals returned to breed a third time (within a year) in our study area. The observation that females disperse greater distances, on average, and occasionally nest at multiple sites separated by a few hundred kilometers suggests that some individuals have multiple locations to which they have a degree of site fidelity. Stenzel et al. (1994) suggested this in an early paper summarising the complex patterns of movements in the plover population they studied around Monterey Bay, California.

Plovers may make dispersal decisions (i.e. where to breed) based on information gained from conspecifics, independent of physical features of habitat. Evidence to support this comes from the observation that naïve plovers (those settling for the first time to breed in our study area) often bred first at locations occupied by plovers that had bred at a site in prior years (experienced; Nelson 2007). Experienced plovers may also use information gained from observing the reproductive success of conspecifics during their wanderings (Stenzel et al. 1994, Colwell et al. 2007). Piping Plovers Chardrius melodus breeding at low densities at the northern extent of their breeding range along the Atlantic coast of North America were more likely to settle at sites where conspecifics had successfully reared young the previous year (Rioux et al. 2011). We did not include "public information" as a variable in our models of dispersal because of the challenges in collating this detailed information over the long breeding season experienced by plovers. It is important to note that these papers did not explicitly test the effect of habitat as the cue used by naïve plovers to select a first breeding site.

We suspect that the low breeding density of plovers in our study area may have interacted with the species' mating system to influence dispersal in other ways. Along the central California coast (e.g. Monterey Bay), plovers breed at higher densities where the mating system has been described as semi-colonial with individuals defending small territories (Warriner et al. 1986, Page et al. 1995). However, in $R U_{2}$, this behaviour is rarely observed. Consequently, individuals probably move more widely in search of mates among sites that occasionally are not occupied by breeding plovers (Burrell and Colwell 2012), which may result in individuals in this population dispersing greater distances between nesting attempts than elsewhere in the species' range due to fewer agonistic interactions with conspecifics. Conversely, the comparatively high return rates of other plover species (Piping Plover, Mountain Plover Charadrius montanus) may stem from the importance of remaining on a territory for successfully acquiring a mate and breeding opportunity (Haig and Oring 1988, Wiens and Cuthbert 1988, Skrade and Dinsmore 2010).

We included in analyses some individuals $(n=11)$ that dispersed $\geq 100 \mathrm{~km}$ to breed at sites in Oregon and Washington. We were not aware of any movements to the south of the study area, although the population was intensively monitored at several locations in the range of the listed segment. These individuals with long-distance dispersals had a large effect on the average distances dispersed both within and between seasons and on model results. When we removed them from analyses, the models had weak explanatory power (nearly all covariates had confidence intervals that overlapped zero). The sole exception was in the case of between-season dispersal by females where prior success and mate retention remained significant, albeit smaller. These findings echo those of others (Jackson 1994, Colwell et al. 2007) stressing the importance of spatial scale and observations of individuals dispersing long distances on analytical results.

\section{Management implications}

Since its listing, recovery efforts have focused on improving the productivity of plovers using various methods of non-lethal predator control, including the common practice of erecting caged exclosures around nests to increase hatching success (Mabee and Estelle 2000, Johnson and Oring 2002, Isaksson 2007). There is general agreement regarding the short-term effectiveness of this management tool in increasing reproductive success, although exclosures have been associated 
with higher rates of nest abandonment (Hardy and Colwell 2008) and increased adult mortality (Johnson and Oring 2002, Isaksson et al. 2007, Hardy and Colwell 2008). Moreover, exclosures have not conclusively resulted in increased recruitment rates (Isaksson et al. 2007) or fledging rates (Hardy and Colwell 2008). Although we included a covariate for exclosures in our models, we found no statistical effect on breeding dispersal of plovers. Nevertheless, given that exclosures increase hatching success (Hardy and Colwell 2008), their use may indirectly affect dispersal behaviour and be counterproductive to some management goals. In lieu of lethal methods, Colwell (2010b) invoked the decision rules hypothesis when he proposed that plovers be allowed to fail in their reproductive attempts at sites where activity of Common Raven Corvus corax and American Crow C. brachyrhynchos was chronically high. In this case, it was thought that failed breeders would disperse and establish themselves at other sites in $\mathrm{RU}_{2}$, where data indicate that reproductive success was higher (Colwell et al. 2010b). However, our results show that most plovers dispersed comparatively short distances; only $22 \%$ and $33 \%$ of male and female dispersals, respectively, were greater than $3 \mathrm{~km}$. Clearly, this distance will not result in plovers moving to better quality habitats. Combined with the finding that immigrant and yearling plovers often settle to breed at sites occupied by conspecifics (Nelson 2007), we conclude that the strategy of "no action" recommended by Colwell et al. (2010b) is ineffective. In its place, more concerted efforts to manage for higher breeding productivity are needed, specifically those to reduce predation on chicks and eggs. Therefore, we urge cooperation among various federal, state, and county agencies, each with their own site-specific management approaches, in solving the problems of population recovery imposed by chronic, high reproductive failure as effected by corvids (Burrell and Colwell 2012, Hardy and Colwell 2012).

\section{Acknowledgements}

We thank. J. Black and M. Gunther for valuable comments that greatly improved the manuscript. We thank Dr. H. Stauffer and Dr. Y. Kim for their guidance in the statistical analysis and D. Lauten and C. Sundstrom who provided data from Oregon and Washington. We owe many thanks to K. M. Brindock, N. S. Burrell, T. J. L. Colwell, J. E. Harris, M. A. Hardy, K. A. Kayano, S. E. McAllister, J. J. Muir, R. R. LeValley, K. G. Ross, K.A. Sesser, S. A. Peterson, R. A. Thiem, and A. N. Transou who assisted in the field. Numerous volunteers and individuals from state and federal agencies conducted surveys. Field work was funded by the California Department of Fish and Game, California Department of Parks and Recreation, Chevron Oil Corporation, Humboldt State University Sponsored Programs Foundation, Mad River Biologists, MRBR, Inc., Marin Rod and Gun Club, MRB Research, Inc., U.S. Bureau of Land Management, U.S. Fish and Wildlife Service, and California Department of Fish and Game's Oil Spill Response Trust Fund through the Oiled Wildlife Care Network at the Wildlife Health Center, School of Veterinary Medicine, University of California, Davis.

\section{References}

Beyer, H. L. (2004) Hawth's analysis tools for ArcGIS. Available online at http://www. spatialecology.com/htools. Accessed on 12 July 2010.

Burnham, K. P. and Anderson, D. R. (2002) Model selection and inference: a practical information-theoretic approach. Second edition. New York, NY: Springer-Verlag.

Burrell, N. S. and Colwell, M. A. (2012) Direct and indirect evidence that productivity of Snowy Plovers Charadrius nivosus varies with occurrence of a nest predator. Wildfowl 62: 202-221.

Catlin, D. H., Rosenberg, D. K. and Haley, K. L. (2005) The effects of nesting success and mate fidelity on breeding dispersal in burrowing owls. Can. J. Zool. 83: 1574-1580.

Clobert, J., Wolff, J. O., Nichols, J. D., Danchin, E. and Dhondt, A. A. (2001) Introduction. Pp xvii - xxi in J. Clobert, E. Danchin, A. A. Dhondt and J. D. Nichols, eds. Dispersal. New York, NY: Oxford University Press. 
Colwell, M. A., Burrell, N. S., Hardy, M. A., Kayano, K., Muir, J. J., Pearson, W. J., Peterson, S. A. and Sesser, K. A. (2010a) Arrival times, laying dates, and reproductive success of Snowy Plovers in two habitats in coastal northern California. J. Field Ornithol. 81: 349-36o.

Colwell, M. A., Burrell, N. S., Hardy, M. A., McAllister, S. E., Pearson, W. J., Peterson, S. A., Ross, K. G. and Sesser, K. A. (2010b) Final report: 2010 Snowy Plover breeding in coastal northern California, Recovery Unit 2. Submitted to MRB Research, Inc., Arcata, $\mathrm{CA}$ and California Department of Fish and Game, Eureka, CA.

Colwell, M. A., McAllister, S. E., Millett, C. B., Transou, A. N., Mullin, S. M., Nelson, Z. J., Wilson, C. A. and LeValley, R. R. (2007) Philopatry and natal dispersal of the Western Snowy Plover. Wilson J. Ornithol. 119: 378-385.

Colwell, M. A., Meyer, J. J., Hardy, M. A., McAllister, S. E., Transou, A. N., LeValley, R. R. and Dinsmore, S. J. (201I) Western Snowy Plovers Charadrius alexandrinus nivosus select nesting substrates that enhance egg crypsis and improve nest survival. Ibis 153 : 303-311.

Emlen, S. T. and Oring, L. W. (1977) Ecology, sexual selection, and the evolution of mating systems. Science 197: 215-223.

Flynn, L., Nol, E. and Zharikov, Y. (1999) Philopatry, nest-site tenacity, and mate fidelity of Semipalmated Plovers. J. Avian Biol. 30: 47-55.

Forero, M. G., Donazar, J. A., Blas, J. and Hiraldo, F. (1999) Causes and consequences of territory change and breeding dispersal distance in the Black Kite. Ecology 80: 1298-1310.

Greenwood, P. J. (1980) Mating systems, philopatry and dispersal in birds and mammals. Anim. Behav. 28: 1140-1162.

Haas, C. (1998) Effects of prior nesting success on site fidelity and breeding dispersal: an experimental approach. Auk 115: 929-936.

Haig, S. M. and Oring, L. W. (1988) Mate, site, and territory fidelity in Piping Plovers. Auk 105: 268-277.

Hanski, I. (2001) Population dynamic consequences of dispersal in local populations and in metapopulations. Pp 283-298 in J. Clobert, E. Danchin, A. A. Dhondt and
J. D. Nichols, eds. Dispersal. New York, NY: Oxford University Press.

Hardy, M. A. and Colwell, M. A. (2008) The impact of predator exclosures on Snowy Plover nesting success: a seven-year study. Wader Study Group Bull. 115: 161-166.

Hardy, M. A. and Colwell, M. A. (2012) Factors influencing Snowy Plover nest survival on ocean-fronting beaches in coastal northern California. Waterbirds 35: 503-511.

Hoover, J. P. (2003) Decision rules for site fidelity in a migratory bird, the Prothonotary Warbler. Ecology 84: 416-430.

Isaksson, D., Wallander, J. and Larsson, M. (2007) Managing predation on groundnesting birds: The effectiveness of nest exclosures. Biol. Conserv. 136: 136-142.

Jackson, D. B. (1994) Breeding dispersal and site-fidelity in three monogamous wader species in the Western Isles, U.K. Ibis 136: $463-473$.

Johnson, M. and Oring, L. W. (2002) Are nest exclosures an effective tool in plover conservation? Waterbirds 25: 184-190.

Lima, S. L. (2009) Predators and the breeding bird: behavioral and reproductive flexibility under the risk of predation. Biol. Rev. 84: $485-513$.

Mabee, T. J. and Estelle, V. B. (2000) Assessing the effectiveness of predator exclosures for plovers. Wilson Bull. 112: 14-20.

Martin, T. E. (1993) Nest predation and nest sites: new perspectives on old patterns. Bioscience 43: 523-532.

Mayfield, H. F. (1975) Suggestions for calculating nest success. Wilson Bull. 87: 456-466.

Minitab 15 Statistical Software. (2007) Minitab, Inc. State College, PA. Available at www. minitab.com. Accessed on 1o February 2011.

Mullin, S. M., Colwell, M. A., McAllister, S. E. and Dinsmore, S. J. (2010) Apparent survival and population growth of Snowy Plovers in coastal northern California. J. Wildl. Manage. 74: 1792-1798.

Nelson, Z. J. (2007) Conspecific attraction in the breeding distribution of the Western Snowy Plover (Charadrius alexandrinus nivosus). M.S. thesis, Department of Wildlife, Humboldt State University, Arcata, CA.

Page, G. W., Warriner, J. S., Warriner, J. C. and Paton, P. W. C. (1995) Snowy Plover (Charadrius alexandrinus). Number 154 in 
A. Poole and F. Gill, eds. The birds of North America. Philadelphia, PA: Academy of Natural Sciences and Washington, DC: American Ornithologists' Union.

Pearson, W. J. (2011) Effects of nest success and mate fidelity on breeding dispersal in a population of Snowy Plovers (Charadrius nivosus). M.Sc thesis. Humboldt State University, Arcata, CA.

Pinheiro, J., Bates, D., DebRoy, S., Sarkar, D. and the R Development Core Team. (201I) Linear and nonlinear mixed effects models (nlme). R package version 3.1-98. Available atwww.cran.r-project.org/package $=$ nlme. Accessed on 12 February 2011.

Ricklefs, R. E. (1969) An analysis of nesting mortality in birds. Smithson. Contrib. Zool. 9: $1-48$.

Rioux, S., Amirault-Langlais, D. L. and Shaffer, F. (2011) Piping Plovers make decisions regarding dispersal based on personal and public information in a variable coastal ecosystem. J. Field Ornithol. 82: 32-43.

Ronce, O., Olivieri, I., Clobert, J. and Danchin, E. (2001) Perspectives on the study of dispersal evolution. Pp. 340-357 in J. Clobert, E. Danchin, A. A. Dhondt and J. D. Nichols, eds. Dispersal. New York, NY: Oxford University Press.

Skrade, P. D. B. and Dinsmore, S. J. (2010) Sex-related dispersal in the mountain plover (Charadrius montanus). Auk 127: 671-677.

Stenzel, L. E., Warriner, J. C., Warriner, J. S., Wilson, K. S., Bidstrup, F. C. and Page, G. W. (1994) Long-distance breeding dispersal of snowy plovers in western North America. J. Anim. Ecol. 63: 887-902.

United States Department of Interior (1993) Threatened status for the Pacific coast population of the Western Snowy Plover. Federal Register 58: 12864-12874.

United States Department of Interior (2007) Western snowy plover (Charadrius alexandrinus nivosus). Pacific coast population recovery plan. Portland, OR: United States Department of Interior.

Warriner, J. S., Warriner, J. C., Page, G. W. and Stenzel, L. E. (1986) Mating system and reproductive success of a small population of polygamous Snowy Plovers. Wilson Bull. 98: $15-37$.

Wiens, T. P. and Cuthbert, F. J. (1988) Nest-site tenacity and mate retention of the Piping Plover. Wilson Bull. 100: 545-553.

WENDY J. PEARSON*, MARK A. COLWELL

Wildlife Department, Humboldt State University, Arcata, California 95521, USA.

*Author for correspondence; email:wendy@tierradata.com

Received 28 July 2012; revision accepted 4 October 2012

Published online 29 October 2013 